\title{
A pneumatologia missionária de Papa Francisco em Evangelii Gaudium
}

\author{
The missionary pneumatology of Pope \\ Francis in Evangelii Gaudium
}

\author{
Marcial Maçaneiro[a], Diogo Marangon Pessotto $^{[\mathrm{b}]^{*}}$ \\ [a] Pontifícia Universidade Católica do Paraná, Curitiba, PR, Brasil \\ ${ }^{[b]}$ Pontifícia Universidade Católica do Rio de Janeiro, Rio de Janeiro, RJ, Brasil
}

\section{Resumo}

A Exortação Apostólica Evangelii Gaudium (EG), do Papa Francisco, dedica especial atenção ao espírito da evangelização, o Espírito Santo, "alma da Igreja evangelizadora" (EG 261), o que nos solicita uma leitura pneumatológica da referida Exortação no intuito de analisarmos os elementos pneumatológicos referidos em sua noção de evangelização mediante o exame, em perspectiva missionária, de suas ocorrências explícitas e implícitas ali postas. O último capítulo de EG, eminentemente pneumatológico, encaminha-nos para o retorno ao seu texto a partir de uma consideração pneumatológico-trinitária. À primazia do Espírito na evangelização associa-se a necessidade de uma autêntica e dócil abertura dos evangelizadores à ação do mesmo Espírito. Fiel ao mandato de Jesus, a Igreja procura anunciar o Evangelho conformando-se a Ele, 
pela ação do Espírito Santo, a fim de que a evangelização não prescinda do testemunho da vida. Cristo foi ungido pelo Espírito para o anúncio da Boa-Nova (Lc 4,18). Assim também a Igreja nascente em Pentecostes foi impelida a evangelizar na força do Espírito Santo (At 2). O Espírito da evangelização em EG, portanto, exprime uma pneumatologia missionária cujos elementos explicitam os nexos entre o Espírito Santo, a Igreja e a missão.

Palavras-chave: Espírito Santo. Evangelização. Igreja. Papa Francisco. Evangelii Gaudium.

\section{Abstract}

The Apostolic Exhortation Evangelii Gaudium (EG), by Pope Francis, devotes special attention to the spirit of evangelization, the Holy Spirit, "the soul of the evangelizing Church" (EG 261), which invites us to a pneumatological reading of this Exhortation in order to analyze the pneumatological elements referred to in his the notion of evangelization by examining, in missionary perspective, his explicit and implicit occurrences therein. The last chapter of EG, eminently pneumatological, leads us to the return to his text from a pneumatological-trinitarian consideration. The primacy of the Holy Spirit in evangelization is associated with the need for an authentic and docile openness of the evangelizers to the action of the same Spirit. Faithful to the mandate of Jesus, the Church seeks to proclaim the Gospel by conforming to it, through the action of the Holy Spirit, so that evangelization does not spare the witness of life. Christ was anointed by the Spirit to announce the Good News (Lk 4, 18). So too the Church at Pentecost was impelled to evangelize in the force and power of the Holy Spirit (Acts 2). The Spirit of evangelization in EG, therefore, expresses a missionary pneumatology whose elements explain the nexuses between the Holy Spirit, the Church and the mission.

Keywords: Holy Spirit. Evangelization. Church. Pope Francis. Evangelii Gaudium.

\section{Introdução}

Aos 24 de novembro de 2013, Francisco entregou à Igreja a Exortação Apostólica Evangelii Gaudium, sobre o anúncio do Evangelho no mundo atual. Após a XIII Assembleia Geral Ordinária do Sínodo dos Bispos, realizada 
entre 7 e 28 de outubro de 2012, com o tema A nova evangelização para a transmissão da fé cristã, Papa Bergoglio convidou toda a Igreja e todos os cristãos a uma "nova etapa evangelizadora" (EG 1), marcada pela alegria do Evangelho a partir do encontro com Jesus Cristo. "Para Papa Francisco uma coisa é absolutamente clara: a Igreja é chamada a anunciar a alegria do Evangelho, correspondendo à sua natureza missionária" (SPADARO, 2014, p. 151, trad. nossa). Nesse sentido, EG exprime seu pressuposto fundamental: a alegria da Igreja e dos cristãos, que deve aparecer ao mundo como sinal e testemunho do encontro com Jesus Cristo, é "uma alegria missionária" (EG 21).

Do ponto de vista histórico, o Sínodo de 2012 foi a razão próxima de EG. O Concílio Vaticano II, a Conferência de Aparecida e a trajetória eclesiástica e pontificado do Papa Bergoglio são do mesmo modo razões históricas que nos possibilitam compreender o sentido do texto de EG. A noção conciliar de aggiornamento e a eclesiologia do Povo de Deus oferecem-nos elementos para uma leitura de EG à luz do Concílio. Ademais, Francisco se insere numa das reflexões teológico-pastorais inauguradas pelo Vaticano II: a relação entre missão e reforma eclesial. Sua atuação como jesuíta na Argentina, atrelada ao espírito da Conferência de Aparecida, da qual participou e da qual extraiu alguns conceitos que utilizou em EG, indicam-nos um contexto mais amplo para a compreensão de suas intenções com tal texto exortativo.

O tema teológico nuclear de EG é certamente a transformação missionária da Igreja (EG 19). Todo o conteúdo de EG converge para a saída missionária (EG 20), para a consecução de um "preciso estilo evangelizador" (EG 18) que leve a Igreja a um "estado permanente de missão" (EG 25). Francisco não tem a intenção de expor sistemática e progressivamente os elementos pertinentes à noção de evangelização. Isso já o fez Paulo VI em Evangelii Nuntiandi (EN). Pressupondo tais elementos, concentra-se em propor uma renovação da Igreja a partir de sua natureza missionária, que conduz, por sua vez, a uma "conversão missionária" (EG 30), que "possui um significado programático e tem consequências importantes" (EG 25). A questão central, portanto, é explicitar como a transformação missionária da Igreja se dá a partir de seus fundamentos, radicados na própria natureza da Igreja, e como é posta em ato pelos sujeitos eclesiais. 
A primeira implicação de tal transformação é a necessidade de um "discernimento evangélico" (EG 50) da realidade atual, discernimento que "é o olhar do discípulo missionário que 'se nutre da luz e da força do Espírito Santo"' (EG 50). Nesse discernimento, conscientizamo-nos das situações, desafios e tentações que paralisam o dinamismo evangelizador da Igreja. Reconhecendo estas possíveis adversidades impostas pela contemporaneidade, Francisco apresenta o anúncio do Evangelho que corresponde ao ideal da reforma missionária da Igreja. Para Spadaro (2014, p. 162), é o tema do anúncio que justifica todo o documento, pois a saída missionária é a saída para anunciar Jesus Cristo ao mundo. Destaca EG a relação entre o Povo de Deus, a evangelização (EG 111) e o querigma (EG 160), mote da renovação da Igreja, o que propriamente exprime a experiência do encontro com Jesus e a consequente atitude de saída para comunicar tal experiência de amor (EG 164).

Somente graças a este encontro - ou reencontro — com o amor de Deus, que se converte em amizade feliz, é que somos resgatados da nossa consciência isolada e da autorreferencialidade [...] Aqui está a fonte da ação evangelizadora. Porque, se alguém acolheu este amor que lhe devolve o sentido da vida, como é que pode conter o desejo de o comunicar aos outros? (EG 8)

Sobremaneira importante e central na ação evangelizadora da Igreja, o querigma possui "repercussões comunitárias e sociais" (EG 177). Trata-se da "dimensão social da evangelização" (EG 176), que, se "não for devidamente explicitada, corre-se sempre o risco de desfigurar o sentido autêntico e integral da missão evangelizadora" (EG 176). "A inclusão social dos pobres" (EG 186) a partir do Evangelho da misericórdia leva a Igreja em saída a reafirmá-los como "os destinatários privilegiados do Evangelho" (EG 48). Critérios para que o Evangelho seja acolhido autenticamente e possa responder às exigências da busca pelo bem comum e da paz são os quatro princípios que Francisco apresenta em EG: "o tempo é superior ao espaço" (EG 222); "a unidade prevalece sobre o conflito" (EG 226); "a realidade é mais importante do que a ideia” (EG 231); e "o todo é superior à parte” (EG 234). 
Por fim, Francisco apresenta as "motivações para um renovado impulso missionário” (EG 262). Assim como Paulo VI em EN¹, Francisco dedica o último capítulo de sua Exortação à ação do Espírito da evangelização, fundamento do espírito da evangelização e princípio da saída missionária da Igreja a partir do paradigma bíblico de Pentecostes. Sendo este o foco do presente trabalho, consideramos que a abordagem de EG acerca do Espírito Santo é decisiva para a compreensão da totalidade do texto de EG. Evangelizar com espírito é evangelizar com o Espírito Santo (EG 261), ao passo que do anúncio que não se dá no Espírito não decorre a Igreja em saída. Não se trata, então, de uma espiritualidade missionária funcional, mas da ação da Terceira Pessoa da Trindade que impele a Igreja a evangelizar, transformando a "autorreferencialidade" (EG 8) em atitude de saída para a missão. Para tanto, Francisco invoca novamente o Espírito: "peço-Lhe que venha renovar, sacudir, impelir a Igreja numa decidida saída para fora de si mesma a fim de evangelizar todos os povos" (EG 261).

À luz das mencionadas motivações, os elementos pneumatológicos de EG que procuraremos analisar são critérios teológicos para a leitura e compreensão do sentido global da Exortação. O critério redacional do documento corresponde ao tema que aborda e às intenções de Francisco: a apresentação da noção de evangelização permeada por suas diretrizes para toda a Igreja. No entanto, o critério formal, que subjaz teologicamente à totalidade do texto, é a Pessoa do Espírito Santo e sua ação na Igreja. O próprio texto nos faz cair na conta dessa relação: “[...] sei que nenhuma motivação será suficiente, se não arde nos corações o fogo do Espírito [...] Ele é a alma da Igreja evangelizadora" (EG 261). Tudo o que foi dito por Francisco em EG carece de sentido se a ação do Espírito na Igreja for desconsiderada. Tal posicionamento reflete de maneira categórica, nos âmbitos da teologia e da pastoral, a recuperação ou o retorno da pneumatologia a partir do Vaticano II. Sendo assim, consideramos que a abordagem teológica da noção de evangelização contida em EG pode e deve contemplar os elementos pneumatológicos

1 Paulo VI, em EN, utiliza o mesmo expediente, assim intitulando o último capítulo de sua Exortação: “0 espírito da evangelização" (EN 74). 
explícitos - propriamente aqueles do último capítulo da Exortação e os que a eles fazem referência - e implícitos — os que conferem sentido ao texto sem, contudo, estarem evidenciados no mesmo texto.

\section{Elementos pneumatológicos em Evangelii Gaudium}

Francisco dedica o último capítulo de EG à relação existente entre a evangelização e o Espírito Santo. Intitulado "Evangelizadores com Espírito", o referido capítulo apresenta aquelas que Francisco considera as principais motivações para um renovado impulso missionário (EG 262-283). O Pontífice torna claro que não tem o objetivo de "oferecer uma síntese da espiritualidade cristã” (EG 260) ou ainda a intenção de explorar os temas da oração, da adoração e da celebração da fé. Importa-lhe "propor algumas reflexões acerca do espírito da nova evangelização" (EG 260). A nova etapa evangelizadora para a qual Francisco convoca toda a Igreja, pautada num "preciso estilo evangelizador" (EG 18), exige a recordação de alguns princípios e atitudes sem os quais o evangelizador perde o entusiasmo missionário e "toda a ação corre o risco de ficar vã e o anúncio, no fim das contas, carecer de alma” (EG 259). Ao conjunto desses princípios e atitudes Francisco atribui o termo espírito, indicando uma "moção interior que impele, motiva, encoraja e dá sentido à ação pessoal e comunitária” (EG 260). Para Francisco, a primeira e mais fundamental motivação não é outra senão o Espírito Santo. Já no início do mencionado capítulo encontramos a seguinte afirmação: "Evangelizadores com espírito quer dizer evangelizadores que se abrem sem medo à ação do Espírito Santo" (EG 259). Nesse sentido, podemos dizer que a palavra espírito - conforme o sentido lato apresentado pode ser substituída pela palavra Espírito, que designa a Terceira Pessoa da Trindade, sendo que as expressões evangelizadores com espírito e espírito da nova evangelização dizem de evangelizadores com Espírito e Espírito da nova evangelização, respectivamente. "Em suma, uma evangelização com espírito é uma evangelização com o Espírito Santo, já que Ele é a alma da Igreja evangelizadora" (EG 261). As motivações da evangelização que seguem ao longo da exposição de Francisco sempre nos remetem à 
primazia da ação do Espírito. O paradigma bíblico que Francisco apresenta ao insistir na ação do Espírito Santo como princípio da evangelização é o do Pentecostes (At 2,1-39). É o Espírito que provoca a saída missionária dos Apóstolos após a efusão do mesmo Espírito e lhes confere ousadia (parresía) para o anúncio intrépido da salvação. Ardorosa, alegre, ousada, corajosa, entusiasta são palavras que Francisco utiliza como qualificantes da ação evangelizadora ocorrida após o Pentecostes. E é justamente essa a evangelização sonhada por Francisco: um novo Pentecostes.

Se a ação evangelizadora da Igreja tem por princípio o Espírito Santo, encontramo-nos diante da possibilidade de uma leitura do texto de EG que não apenas evidencie os elementos pneumatológicos explícitos como também torne claros os elementos pneumatológicos implícitos ao longo de toda a Exortação. O estilo evangelizador proposto por Francisco em EG está fundado na ação do Espírito, que é o princípio gerador da Igreja e princípio de sua unidade, santidade e catolicidade. Da saída missionária da Igreja à conversão de suas estruturas pastorais; do contínuo retorno ao Evangelho às tentações dos agentes pastorais; do anúncio do Evangelho à dimensão social da evangelização; todos esses aspectos da evangelização carecem de sentido se lhes falta o princípio pneumatológico.

A pneumatologia ou a Trindade não são os temas centrais de EG. Entretanto, a leitura do texto de Francisco nos atesta que o fundamento da evangelização é trinitário. Assim, a proposta de uma leitura trinitária de EG nos permite verificar como se constitui a relação entre a Trindade, a Igreja e a Evangelização. Focalizamos, então, nossa atenção na Pessoa do Espírito em sua relação com a missão, uma vez que EG trata do Espírito no conjunto de sua abordagem teológico-pastoral sobre a evangelização. Daí se justifica a leitura pneumatológica da Exortação.

Com vistas à argumentação sobre as questões levantadas, organizamos nossa exposição em alguns pontos a partir do texto de EG: a) o Espírito como amor do Pai e do Filho, que trata da teologia trinitária de Francisco; b) a eclesiologia do Povo de Deus e o Espírito Santo, que se refere ao fundamento pneumatológico da Igreja evangelizadora; c) o Espírito como protagonista da ação missionária da Igreja, que apresenta a prioridade do Espírito Santo na evangelização; d) o Espírito Santo e os evangelizadores, que discorre sobre a ação do Espírito nos agentes da evangelização; e) os 
carismas do Espírito para a missão, que expõe a ação do Espírito para a edificação da Igreja; e f) a renovação eclesial a partir do Espírito Santo, na esteira do Concílio Vaticano II e da reforma missionária da Igreja.

\section{O Espírito Santo, Amor do Pai e do Filho}

Ao afirmar a Igreja como mistério, cujas raízes estão na Trindade², o Concílio Vaticano II lançou as bases do fundamento trinitário da evangelização, pois o ser e o agir da Igreja vinculam-se essencialmente ${ }^{3}$. A missão, nesse sentido, não é um acessório ou um acidente eclesial. Ao contrário, exprime a natureza da Igreja, o mistério de comunhão trinitário do qual participa e ao qual deve levar todos os homens e mulheres. Por essa razão, salienta-se a fecunda articulação entre a teologia fundamental e a eclesiologia enquanto referida à evangelização. Uma adequada compreensão eclesial decorre necessariamente de uma adequada compreensão da Trindade e da relação de comunhão entre as Três Pessoas. Trata-se de um contínuo processo hermenêutico da Revelação expressa no decorrer da história da salvação, processo orientado pelo evento Cristo ${ }^{4}$. Ora, se a evangelização está no âmago da eclesiologia e esta funda-se no mistério trinitário, o princípio da missão eclesial é a mesma Trindade ${ }^{5}$.

Francisco parte desse pressuposto fundamental para postular a prioridade do Espírito Santo na evangelização. O texto da Exortação torna claro que o Pontífice fundamenta sua noção de evangelização no mistério trinitário. Dado que procuramos apresentar em que medida essa noção se constitui a partir de seus elementos pneumatológicos, explicitaremos como EG concebe a Pessoa do Espírito Santo na dinâmica trinitária, de

2 Cf. LG 1-8.

3 "A Igreja peregrina é por natureza missionária. Nasce, segundo o desígnio divino, da própria missão do Filho e do Espírito Santo" (AG 2).

4 Segundo Hackmann (2013, p. 93), a perspectiva da eclesiologia de comunhão une dois aspectos que, via de regra, são entendidos separadamente: 0 teológico e o pastoral, a comunhão e a missão. A partir do modelo da unidade trinitária, a Igreja vive a comunhão interna (sua essência) e a promove externamente (a missão).

5 Cf. AG 2. 
modo que tal relação serve de base para a consideração da Terceira Pessoa da Trindade como protagonista da evangelização.

Em EG, Francisco faz trinta e sete referências ao Pai, destacando seu mistério de amor e sua relação com o Filho e o Espírito ${ }^{6}$. Fica evidente a insistência de Francisco quanto aos atributos do amor e da misericórdia relativos ao Pai. Se, "em última instância, o que procuramos é a glória do Pai" (EG 267), assim como o fez Jesus, e se "evangelizamos para a maior glória do Pai que nos ama” (EG 267), nossa vida tem seu princípio e seu fim no Amor, no Pai. O Pai é o Amor, cuja expressão plena é a misericórdia. Este acento que Francisco confere ao Pai relaciona-se com o centro da atividade evangelizadora da Igreja: o querigma, como ação do Espírito que nos faz crer em Jesus que nos revela e comunica a misericórdia do Pai (EG 164). A experiência do Pai é, então, a experiência de se descobrir infinitamente amado por Deus.

trata-se de uma experiência profunda e intensa que [...] convida o homem a compartilhar com os outros o amor divino. Desse modo, apresenta-se a ele um desafio de caráter permanente: anunciar, ensinar e testemunhar esse amor que o precedeu e elegeu. Em outras palavras, pede-se ao homem que mostre a todo homem que Deus o ama imensamente [...] (JUNCOS; LIBERTI, 2015, p. 52, trad. nossa).

A Jesus Cristo Francisco faz cento e noventa e duas referências ${ }^{7}$, novamente evidenciando o atributo do amor. O Filho manifesta o amor salvífico do Pai, porque para isso foi enviado ${ }^{8}$. No encontro com o Filho,

6 A misericórdia do Pai (EG 24), revelada e comunicada por Jesus (EG 164); 0 abraço batismal do Pai (EG 144); a adoção gratuita do Pai e o dom de sua graça (EG 162); o Pai e o Filho que enviam o Espírito (EG 117); o Pai que ama infinitamente cada um (EG 178); o Pai que ouve o clamor dos pobres (EG 187); a glória devida ao Pai (EG 267); a Igreja como casa aberta do Pai (EG 47); a Igreja povo de Deus, projeto de amor do Pai (EG 114).

7 A alegria do encontro pessoal com Jesus (EG 1) e com o seu amor que nos salva (EG 264); o Cristo, morto e ressuscitado, que manifesta o amor salvífico de Deus (EG 7,36); Jesus, o primeiro e o maior evangelizador (EG 12); a evangelização como mandato de Jesus (EG 19) e sinal do Reino trazido por Ele (EG 48); Jesus que exulta no Espírito e louva o Pai (EG 21); a Igreja enviada por Jesus como sacramento da salvação (EG 112) e sua reforma por fidelidade a Cristo (EG 26); o anúncio explícito de Jesus como Senhor (EG 110); 0 amor de Jesus levado aos outros pelo discípulo (EG 127); deixar-se transformar em Cristo (EG 162); o querigma (EG 164); Jesus que instaura o Reino de seu Pai (EG 180); Jesus que se identificou com os mais pequenos (EG 209); Jesus que procurou a glória do Pai (EG 267).

8 Cf. Jo 3,16 . 
experimentamos o seu amor, que é o amor do Pai. Para EG, esse encontro com o amor de Deus - amor do Pai e do Filho - é a "fonte da ação evangelizadora" (EG 8), porque a acolhida deste amor recupera para o ser humano o sentido da vida e não há como conter o desejo de comunicar essa experiência às outras pessoas (EG 8).

Contemplando a imagem do Pai presente no Filho, caímos na conta do profundo amor de um Deus feito homem que abraçou a proximidade como atitude evangelizadora de cada dia. Este é o rosto vivente, a identidade do amor divino que ilumina a vida do homem a partir de um encontro pessoal e transformador. Por isso, o Papa Bergoglio afirma: "Jesus Cristo te ama [...] e agora está vivo a teu lado a cada dia, para iluminar-te, para fortalecer-te, para libertar-te" (EG 164) (JUNCOS; LIBERTI, 2015, p. 53 , trad. nossa).

É no Mistério Pascal de Jesus que o amor do Pai é plenamente revelado. Francisco ressalta inúmeras vezes a ação do Ressuscitado ${ }^{9}$ como o horizonte definitivo de sua missão salvadora, de modo que sua Morte e Ressurreição exprimem a totalidade do amor.

Ao Espírito Santo Francisco faz oitenta e quatro referências ${ }^{10}$. De acordo com Juncos e Liberti (2015, p. 56), o Espírito Santo é a força que encoraja o discípulo missionário a comunicar a experiência do encontro pessoal e transformador que vivenciou com o Deus-Amor. EG põe em destaque o amor de Deus, reportando-o à Pessoa do Espírito Santo.

9 Cf. EG 2, 11, 19, 30, 36, 77, 95, 167, 275, 288.

10 A vida no Espírito que jorra do coração do Cristo ressuscitado (EG 2); a força do Espírito que nos faz evangelizadores (EG 12); o Espírito que suscita instituições, comunidades e movimentos na Igreja (EG 29); 0 amor ao próximo e a graça interior do Espírito (EG 37); o discernimento evangélico (EG 50); o Espírito é a cura para o mundanismo espiritual (EG 97); o Espírito que nos faz filhos de Deus no amor (EG 112); o Espírito que fecunda as culturas com a força do Evangelho (EG 116) e embeleza a Igreja num povo evangelizado (EG 116); o Espírito, vínculo de amor entre o Pai e o Filho, é o princípio da comunhão e da unidade (EG 117); o Espírito que guia o povo de Deus na verdade e o conduz à salvação, conferindo aos cristãos certa conaturalidade com as realidades divinas (EG 119); o Espírito que enriquece, renova e edifica a Igreja com carismas (EG 130); o Espírito Santo que age nos evangelizadores (EG 151); o Espírito que nos conforma a Cristo (EG 162); o querigma, fogo do Espírito (EG 164); a ação libertadora do Espírito (EG 178); o Espírito que trabalha como, quando e onde quer (EG 279); a confiança e a docilidade ao Espírito Santo (EG 280).

Rev. Pistis Prax., Teol. Pastor., Curitiba, v. 10, n. 3, 551-590, set./dez. 2018 
É o Espírito Santo, enviado pelo Pai e o Filho, que transforma os nossos corações e nos torna capazes de entrar na comunhão perfeita da Santíssima Trindade, onde tudo encontra a sua unidade. O Espírito Santo constrói a comunhão e a harmonia do povo de Deus. Ele mesmo é a harmonia, tal como é o vínculo de amor entre o Pai e o Filho (EG 117).

A experiência do amor do Pai, em Cristo, só é possível pela ação do Espírito Santo. Razão disso é que o Espírito é o próprio amor do Pai e do Filho. A centralidade do amor de Deus e do encontro pessoal com Cristo como condição para a experiência desse amor em EG tem seu ponto de apoio na Pessoa do Espírito Santo, porque é Ele que nos faz participantes da comunhão trinitária. Sendo esta uma comunhão de amor, temos que o Espírito Santo é o Amor, e é assim que Francisco concebe o Espírito, procedendo de modo semelhante ao que faz com o Pai e o Filho. Deus "envia o seu Espírito aos nossos corações, para nos fazer seus filhos, para nos transformar e tornar capazes de responder com a nossa vida ao seu amor" (EG 112). São Paulo escreve sobre essa realidade aos Romanos: “[...] porque o amor de Deus foi derramado em nossos corações pelo Espírito Santo que nos foi dado" (Rm 5,5).

A "interioridade entre o Espírito e o fiel é amor: provoca união por meio do Pai e do Filho. Ele está presente enquanto comunhão de pessoas [...] Ele é comunhão, o amor que 'amorifica'. Por meio de sua presença o fiel pertence a Cristo (Rm 8,9)" (HACKMANN, 2013, p. 303). Para Cantalamessa (2014, p. 213), o Espírito Santo é Aquele de quem fala a Escritura: "Deus é amor" (1Jo 4,8.16). Em Deus tudo é amor, mas o Espírito Santo, Pessoa Divina, também o é em sentido pessoal. Se o amor "procede de Deus" (1Jo 4,7), é justamente o Espírito que procede de Deus como amor. Se EG apresenta a experiência do amor de Deus como o evento fundante da ação evangelizadora (EG 8) - experiência que deve ser comunicada a fim de que todos possam vivenciá-la - e se o amor de Deus é o próprio Espírito Santo, concluímos que há uma relação de consonância absoluta entre a centralidade do amor de Deus e a afirmação do Espírito como "alma da Igreja evangelizadora" (EG 261). A Igreja e os cristãos encontram-se inseridos nessa comunhão do Espírito-Amor e por isso são impelidos a anunciá-lo. 
Isso não significa a inexistência de outras considerações acerca da Terceira Pessoa da Trindade em EG. Uma que Francisco põe em relevo é a do Espírito como doador da vida nova em Cristo, a vida no Espírito (EG 275280). Todavia, mesmo essa consideração corrobora a concepção do Espírito como Amor: "As obras de amor ao próximo são a manifestação externa mais perfeita da graça interior do Espírito: 'O elemento principal da Nova Lei é a graça do Espírito Santo, que se manifesta através da fé que opera pelo amor"'11 (EG 37). Segundo Maçaneiro (2016, p. 647), "o Pai que eternamente comunica seu amor ao Filho no Espírito, decidiu abrir aos homens o diálogo da salvação, derramando sobre nós o mesmo amor comunional que reinava na intimidade trinitária”, ou seja, derramando o Espírito Santo.

Desse modo, a concepção de Espírito que EG enfatiza é a do Espírito como amor, pois é a experiência do amor de Deus a fonte da evangelização. A motivação fundamental para evangelizar é o Espírito Santo (EG 261) como amor do Pai e do Filho que nos comunica o amor e a misericórdia de Deus, núcleo da mensagem evangelizadora. O Espírito é o amor fontal, amor do Pai e do Filho, de quem procede o mesmo Espírito. O Espírito Santo é penhor e testemunha do amor com que Deus nos ama. No Espírito, amamos nossos irmãos com o mesmo amor com que o Pai ama o Filho. Amar os irmãos, nesse sentido, é comunicar-lhes o Amor, anunciar-lhes o Evangelho, o mesmo que experimentamos existencialmente por obra do Espírito Santo. Miranda (1998, p. 166) nos auxilia na compreensão da relação entre o Espírito como dom e o Espírito como amor do Pai e do Filho:

[...] a plenitude da verdade é o amor que é Deus (1 Jo 4,8) e que se revela em Jesus Cristo, sendo o Espírito no seio da Trindade este amor recíproco entre o Pai e o Filho [...] Assim só pode chegar à "verdade plena" que é esta vida, que é este amor de Deus manifesto na História, aquele que, acolhendo o Espírito, passa a viver este amor teologal (de Deus) [...] a ação do Espírito, como Aquele que introduz na e interpreta a verdade que é Jesus Cristo, não se enquadra numa atividade meramente racional. Acolher o Espírito de Cristo (Rm 8,9) implica traduzir na vida o seu dinamismo de amor. Com outras palavras, o seguimento real de Cristo é condição, sem mais, para conhecê-lO. E como este configurar-se com Cristo é obra do Espírito que inspira e capacita nossa liberdade, tanto mais se torna perceptível a atuação do

11 Referência de EG à Summa Theologica (Summa Theologica -II, q. 108, a. 1).

Rev. Pistis Prax., Teol. Pastor., Curitiba, v. 10, n. 3, 551-590, set./dez. 2018 
Espírito quanto mais vivermos a existência de Cristo, uma "existência no Espírito" no sentido mais profundo da expressão.

O Espírito da evangelização é prioritariamente o Espírito Amor ${ }^{12}$, que nos concede experienciar o amor de Deus em Cristo para assumirmos seu programa de vida e comunicarmos tal experiência aos homens e mulheres na missão. Nas palavras de João Paulo II:

Na sua vida íntima Deus "é Amor", amor essencial, comum às três Pessoas divinas: amor pessoal é o Espírito Santo, como Espírito do Pai e do Filho. Por isso ele "perscruta as profundezas de Deus", como Amor-Dom incriado. Pode dizer-se que, no Espírito Santo, a vida íntima de Deus uno e trino se torna totalmente dom, permuta de amor recíproco entre as Pessoas divinas; e ainda, que no Espírito Santo Deus "existe" à maneira de Dom. O Espírito Santo é a expressão pessoal desse doar-se, desse ser-amor. É Pessoa-Amor. É Pessoa-Dom (DeV 10).

Implícita ao texto de EG, portanto, temos uma significativa teologia trinitária, que reconhece o Espírito como Amor no seio da Trindade. Dessa forma, para Francisco, tal caracterização do Espírito é a que mais corresponde à natureza missionária da Igreja e aos laços recíprocos entre a Trindade, a Igreja e a evangelização.

\section{Igreja, Povo de Deus constituído e congregado no Espírito Santo}

A categoria povo, e, por consequência, povo de Deus, é muito cara a Francisco ${ }^{13}$. Não é por acaso que inicia o terceiro capítulo com uma significativa exposição sobre a relação entre o povo de Deus e a evangelização (EG 111). O princípio que dispõe sua argumentação é o de

12 A "vida divina tem como princípio intrínseco e quase-formal, o Espírito, amor que une o Pai e o Filho, e que nos é comunicado, fazendo brotar no cristão uma vida de filhos de Deus, pois é no Espírito que chamamos a Deus de Abba. Assim o Espírito se nos manifesta não diretamente como pessoa, mas como amor qualificante, por assim dizer, da vida divina de que participamos, amor que une o Pai ao Filho e o Filho ao Pai, amor divino" (CATÃ0, 2009, p. 101).

13 A influência que recebeu da Teologia do Povo argentina foi responsável pela formação de grande parte de seu pensamento teológico. 
que "todo o povo de Deus anuncia o Evangelho". Neste estão contidos importantes elementos trinitários e pneumatológicos.

A Igreja, como sujeito da evangelização, "é mais do que uma instituição orgânica e hierárquica; é, antes de tudo, um povo que peregrina para Deus" (EG 111). Francisco faz aqui referência ao mistério trinitário da Igreja $^{14}$. O povo de Deus é imagem da Trindade, constituído pela vontade salvífica do Pai manifestada na missão e na obra do Filho e na missão do Espírito que santifica e vivifica a Igreja. Em termos pneumatológicos, a Igreja foi "manifestada pela efusão do Espírito" (LG 2) em Pentecostes, de modo que o Espírito é coinstituinte da Igreja. "Trata-se da Igreja histórica e visível, aquela da qual Jesus é o 'fundador' (mas, sempre vivo e ativo, ele é o seu fundamento permanente). O Espírito lhe dá vida e a faz crescer enquanto ela é Corpo de Cristo" (CONGAR, 2010, p. 18). Sendo assim, a categoria Igreja Povo de Deus, eminentemente trinitária, exprime a realidade de um povo constituído e congregado no Espírito Santo para a comunhão com Deus e para o testemunho dessa comunhão. Sob o prisma da evangelização, essa realidade exprime a "primazia da graça" (EG 112), pois a primeira palavra, a iniciativa e a atividade verdadeiras vêm de Deus. A primazia da graça é a primazia do Espírito, cuja ação convocou e convoca a todos como povo (LG 9) para a salvação. "Ninguém se salva sozinho, isto é, nem como indivíduo isolado, nem por suas próprias forças. Deus nos atrai no respeito da complexa trama de relações interpessoais que a vida numa comunidade humana supõe. Esse povo, que Deus escolheu para si e convocou, é a Igreja" (EG 113).

O povo de Deus, contudo, não é uma realidade homogênea. Encarnando-se nos diversos povos da Terra, cada povo possui uma cultura própria, que se exprime na totalidade de sua vida. "A noção de cultura é um instrumento precioso para compreender as diversas expressões da vida cristã que existem no povo de Deus" (EG 115). Deus age e convoca os seres humanos à salvação e à comunhão com Ele no âmbito dos povos culturalmente situados. "A graça supõe a cultura, e o dom de Deus encarna-se na cultura de quem o recebe" (EG 115). O primeiro elemento pneumatológico referido ao povo de Deus em EG diz da própria natureza

14 Cf. LG 9. 
da Igreja, constituída no Espírito Santo como "povo com muitos rostos" (EG 115), nos quais o mesmo Espírito age a partir de dentro, de sua realidade mistérica, de modo que "a comunhão dos fiéis e das Igrejas locais do Povo de Deus se sustenta na comunhão com a Trindade” (DAp 155).

Um segundo elemento pneumatológico refere-se à inculturação do Evangelho. Se a própria natureza da Igreja Povo de Deus supõe a heterogeneidade dos povos, também o anúncio do Evangelho a estes supõe que suas experiências de fé e seus modos de transmiti-la tenham em conta seus elementos culturais.

Quando uma comunidade acolhe o anúncio da salvação, o Espírito Santo fecunda a sua cultura com a força transformadora do seu Evangelho [...] Nos diferentes povos, que experimentam o dom de Deus segundo a própria cultura, a Igreja exprime a sua genuína catolicidade e mostra "a beleza deste rosto pluriforme”. Através das manifestações cristãs de um povo evangelizado, o Espírito Santo embeleza a Igreja, mostrando-lhe novos aspectos da Revelação e presenteando-a com um novo rosto (EG 116).

A ação do Espírito nos diversos povos da terra se dá tanto no acolhimento da salvação como também nas diferentes formas por meio das quais esses povos igualmente evangelizam. O Espírito não apenas fecunda as muitas culturas com o Evangelho como também, por meio dessas culturas, apresenta à Igreja novos aspectos da Revelação, que certamente não seriam percebidos no caso de uma uniformidade cultural cristã. A diversidade cultural no contexto da inculturação do Evangelho é uma riqueza para a Igreja, pois é na diversidade que se explicita de modo mais evidente a unidade eclesial, da qual o Espírito Santo é princípio.

É o Espírito Santo, enviado pelo Pai e o Filho, que transforma os nossos corações e nos torna capazes de entrar na comunhão perfeita da Santíssima Trindade, onde tudo encontra a sua unidade. O Espírito Santo constrói a comunhão e a harmonia do povo de Deus. Ele mesmo é a harmonia, tal como é vínculo de amor entre o Pai e o Filho. É Ele que suscita uma abundante e diversificada riqueza de dons e, ao mesmo tempo, constrói uma unidade que nunca é uniformidade, mas multiforme harmonia que atrai. A evangelização reconhece com alegria estas múltiplas riquezas que o Espírito gera na Igreja (EG 117). 
Portanto, é o Espírito que transforma os povos em Povo de Deus evangelizador. Acaso evangelizar não é, em sentido estrito, anunciar e testemunhar Jesus Cristo a fim de que todos os homens e mulheres entrem nessa comunhão de amor com Deus? Para Francisco, todo o Povo de Deus evangeliza porque experimenta, cada povo a seu modo, essa comunhão no Espírito. O DAp afirma, citando Puebla: “Todos os batizados e batizadas [...] 'através do sacerdócio comum do Povo de Deus', somos chamados a viver e a transmitir a comunhão com a Trindade, pois 'a evangelização é um chamado à participação da comunhão trinitária”' (DAp 157).

\section{Espírito Santo, protagonista da evangelização}

É no capítulo V de EG que Francisco apresenta de modo explícito os elementos pneumatológicos que motivam e conferem sentido à ação evangelizadora da Igreja. Francisco utiliza expressões específicas para designar o referido sentido, sendo que tais expressões denotam uma aparente intenção de situar a ação do Espírito Santo e sua prioridade na evangelização a partir da pessoa humana, imago Dei, que vive na comunidade eclesial. Francisco indica "uma moção interior" (EG 261, grifo nosso), "motivações para um renovado impulso missionário" (EG 262, grifo nosso). Essas disposições e motivações são o espírito da evangelização, o que "impele, motiva, encoraja e dá sentido à ação pessoal e comunitária" (EG 261). Isso se dá no interior dos evangelizadores pela ação do Espírito Santo. Este princípio teológico encontra eco nas palavras de Francisco: "O princípio da primazia da graça deve ser um farol que ilumine constantemente as nossas reflexões sobre a evangelização" (EG 112). A graça é o Espírito Santo, que torna os cristãos participantes da missão de Jesus. Em outras palavras, a Igreja e os cristãos não evangelizam por si mesmos, ou em virtude de uma escolha pessoal ou comunitária, mas o fazem por graça, por iniciativa de Deus. A graça que lança à missão é 
o Espírito Santo, "alma da Igreja evangelizadora" (EG 261)15. O binômio espírito-Espírito, presente em $\mathrm{EG}^{16}$, aponta o espírito humano como o lugar da graça no qual age o Espírito. Constituída como Povo de Deus, a Igreja é projetada à missão pelo mesmo Espírito, que santifica e conforma os cristãos a Cristo em prol do anúncio do Reino e da salvação.

Em EG, Francisco apresenta o Pentecostes como o evento paradigmático dos "evangelizadores com espírito" (EG 259). Trata-se da única referência bíblica da qual o Pontífice se vale para introduzir sua reflexão acerca do "espírito da nova evangelização" (EG 260). Há dois aspectos que Francisco salienta ao mencionar o Pentecostes. O primeiro diz do Espírito que transforma os apóstolos em anunciadores das maravilhas de Deus, fazendo-os sair de si mesmos para tal. O segundo diz do Espírito que os faz anunciadores ousados (EG 259). Podemos dizer que estas são as realidades ou os elementos que fundamentam teologicamente a primazia do Espírito na evangelização. Questão relevante que subjaz ao pensamento de Francisco é o fato de que é o Espírito Santo que confere a autenticidade, a eficácia e a fecundidade da ação de evangelização da Igreja: quanto ao Espírito, "invoquemo-Lo hoje [...] sem o qual toda a ação corre o risco de ficar vã e o anúncio, no fim das contas, carece de alma" (EG 259). Noutro lugar: "uma evangelização com espírito é muito diferente de um conjunto de tarefas vividas como uma obrigação pesada, que quase não se tolera ou se suporta como algo que contradiz as nossas próprias inclinações e desejos" (EG 261). Sob o prisma do Pentecostes, observamos que só após a vinda do Espírito Santo os Apóstolos compreenderam e

15 “Há uma tradição teológica que emprega a simbologia da relação existente entre a alma e o corpo humano para exprimir a união íntima entre o Espírito Santo e a Igreja. Os Santos Padres usam a expressão de que o Espírito Santo é a alma da Igreja, ou a alma do Corpo de Cristo, para expressar essa união [...] Essa alma, à qual se referem os Santos Padres, não é uma alma que constitua um todo substancial com o corpo, pois o Espírito Santo é transcendente à Igreja, apesar de ser, também, imanente a ela, enquanto age nela [...] 0 Espírito Santo realiza na Igreja a função que a alma exerce no corpo, ao estar presente no Corpo de Cristo, que é a Igreja. 0 mesmo Espírito está presente, ao mesmo tempo, na cabeça, que é Jesus Cristo, e em seus membros, que são os batizados, os fiéis" (HACKMANN, 2013, p. 86).

16 A expressão espírito, enquanto referida à evangelização, diz das motivações interiores mais fundamentais da pessoa, motivações que dão sentido a seu agir evangelizador. A expressão Espírito refere-se ao Espírito Santo, Terceira Pessoa da Trindade, que é a motivação fundamental para a evangelização. No contexto de EG, podemos afirmar, seguindo as palavras de Boff (2015, p. 377), que tal binômio indica "a vida do Espírito Santo em nosso espírito. É a nossa vida vivida segundo o Espírito".

Rev. Pistis Prax., Teol. Pastor., Curitiba, v. 10, n. 3, 551-590, set./dez. 2018 
experimentaram o amor do Cristo morto e ressuscitado. A insistência de EG na evangelização com espírito insere-se nessa perspectiva: os cristãos conhecem a Jesus e empreendem a ação evangelizadora da Igreja em seus mais diversos aspectos; contudo, esta não será autêntica e efetiva se lhes faltar a ação e a moção do Espírito, tal como em Pentecostes. Francisco parece reconhecer que o maior perigo ao qual a evangelização está exposta é o de prescindir da ação do Espírito Santo, sem a qual tudo o mais fica desprovido de sentido ${ }^{17}$. Daí a preocupação de EG em apresentar o Espírito Santo como o Espírito da missão.

Mas sei que nenhuma motivação será suficiente, se não arde nos corações o fogo do Espírito. Em suma, uma evangelização com espírito é uma evangelização com o Espírito Santo, já que Ele é a alma da Igreja evangelizadora. Antes de propor algumas motivações e sugestões espirituais, invoco uma vez mais o Espírito Santo; peço-Lhe que venha renovar, sacudir, impelir a Igreja numa decidida saída para fora de si mesma a fim de evangelizar todos os povos (EG 261).

Assim como ocorreu com os Apóstolos no Pentecostes, à Igreja e aos cristãos é necessária a abertura à novidade do Espírito para que Ele nos confira a audácia da missão. Para Pérez (2014, p. 331, trad. nossa),

em uma verdadeira acolhida e recepção do Espírito está a chave de toda a evangelização, reforma ou revolução. Os evangelizadores hão de ter o Espírito. Sem ele, sem o Espírito Santo e sem o espírito interior que anima a vida de cada crente, alma verdadeira das instituições e das estruturas, no fundo tudo permaneceria igual e toda proposta seria letra morta.

É por isso que o Espírito Santo é o princípio da ação evangelizadora da Igreja. A evangelização não deve estar submetida a outros critérios e a outras motivações que não as do Espírito. O primeiro efeito do Espírito

170 mundanismo espiritual "também se pode traduzir em várias formas de se apresentar a si mesmo envolvido numa densa vida social cheia de viagens, reuniões, jantares, recepções. Ou então desdobra-se num funcionalismo empresarial, carregado de estatísticas, planificações e avaliações, onde o principal beneficiário não é o povo de Deus mas a Igreja como organização" (EG 95). "Este mundanismo asfixiante cura-se saboreando o ar puro do Espírito Santo, que nos liberta de estarmos centrados em nós mesmos, escondidos numa aparência religiosa vazia de Deus" (EG 97). 
naqueles que se abrem à sua ação é o impulso para a missão ${ }^{18}$. Poderíamos afirmar que, no contexto de EG, a vida no Espírito é um elemento pressuposto e indissociável da missão impulsionada pelo Espírito: é na missão que o evangelizador progride na vivência da santidade e é esta vida no Espírito que torna sempre mais eficaz a ação missionária. O ardor, a alegria, a generosidade, a ousadia, o amor — todas estas realidades pertinentes à vida no Espírito - estão relacionadas essencialmente com a evangelização (EG 261), de tal modo que "Jesus quer evangelizadores que anunciem a Boa Nova, não só com palavras mas sobretudo com uma vida transfigurada pela presença de Deus" (EG 259), com parresía ${ }^{19}$, "em voz alta e em todo o tempo e lugar" (EG 259).

Se é o Espírito a alma da Igreja evangelizadora, sem Ele não há missão. A analogia de alma presente em EG diz prioritariamente daquilo que se deve dar na missão eclesial de cada batizado, de cada evangelizador: a ação do Espírito a qual todos são chamados a abrir-se. Se a Igreja existe para evangelizar e sua alma, aquilo que a constitui como princípio vital a partir de Cristo-Cabeça, é o Espírito Santo, o mesmo Espírito é, por conseguinte, a alma da evangelização, seu princípio. Evangelizar com alma, ou com espírito, é realizar o dinamismo próprio e mais fundamental da Igreja, a saber, o mistério da Igreja missionária, que se manifesta na relação entre o Espírito Santo e os batizados, o Povo de Deus evangelizador, que atualiza nas mais diversas culturas o mistério de Cristo, a Boa Nova do Pai. Temos aí a centralidade do Pentecostes e do Espírito da missão para Francisco: o anúncio e o testemunho de Jesus só são possíveis quando o conhecemos, sendo que, para isso, faz-se necessário permitirmos que o Espírito Santo nos abra os olhos, os ouvidos e o coração. A Igreja evangelizadora, movida pelo Espírito Santo, evangeliza integralmente, ou seja, em todas as suas dimensões, pelo caminho da santidade, que é amor para fora ${ }^{20}$. Nesse sentido, evangelizar com o Espírito Santo é encarnar o

18 “[...] se uma pessoa experimentou verdadeiramente o amor de Deus que o salva, não precisa de muito tempo de preparação para sair a anunciá-Io" (EG 120).

19 Atitude dos apóstolos após o Pentecostes (cf. At 5,41-42). Trata-se do anúncio com alegria e destemor: uma alegria corajosa ou uma coragem alegre.

20 A integralidade da missão rechaça toda e qualquer forma de autorreferencialidade (EG 8). 
amor de Deus manifestado no Cristo morto e ressuscitado para além de nós mesmos, exatamente o que verificamos no que seguiu ao Pentecostes.

Em uma de suas homilias nas Missas diárias em Santa Marta, afirmou Francisco acerca do trecho dos Atos dos Apóstolos que trata do encontro entre o Apóstolo Felipe e o etíope: "É Ele que faz as coisas. É o Espírito que faz nascer e crescer a Igreja" ${ }^{21}$, de modo que a Igreja nos propõe a docilidade a Ele, que é justamente a atitude do cristão. "[...] esta docilidade faz de modo que o Espírito possa agir e ir avante para construir a Igreja”. O Espírito da missão, para Francisco, é o Espírito que põe a Igreja numa constante atitude de abertura e disponibilidade para ir e anunciar o Evangelho. Assim como a alma dá a vida e confere vitalidade ao corpo, assim também o Espírito não só dá vida à Igreja como a anima e impulsiona para anunciar Jesus Cristo e o chamado universal à comunhão com Deus.

Francisco, portanto, enfatiza o Espírito da evangelização como força e potência, como impulso para a missão. A Igreja "em saída" (EG 20) o é na força do Espírito, pois é o mesmo Espírito que, à luz do Pentecostes, faz "sair da própria comodidade e ter a coragem de alcançar todas as periferias que precisam da luz do Evangelho" (EG 20). É o Espírito Santo que realiza a conversão pastoral e missionária, necessária e urgente, colocando a Igreja em "estado permanente de missão" (EG 25). É o Espírito que, impulsionando a Igreja à missão, dissipa concepções e práticas pastorais autorreferenciais. É o Espírito que nos torna discípulos missionários, pois a vida em Cristo não se encontra à parte da atividade missionária. A expressão que articula o sentido global de EG é a saída missionária da Igreja. Para o hoje eclesial, Francisco entende ser esta a atitude fundamental. Ora, se o mesmo Pontífice afirma que o espírito da nova evangelização é o espírito que realiza a saída para a missão o Espírito Santo - a pneumatologia em EG enquanto critério teológico para a leitura do documento explicita o Espírito da missão, tal como Lucas apresenta em seu Evangelho e nos Atos dos Apóstolos. De acordo com Boff (1996, p. 21), a concepção de espírito (pneuma) no Evangelho de Lucas designa a força de Deus, necessária para a realização de ações específicas. O Espírito Santo é, então, um dom que dá força para uma missão particular,

21 FRANCISCO. Homilia na Quinta-feira da 3ª Semana da Páscoa, 14 de abril de 2016.

Rev. Pistis Prax., Teol. Pastor., Curitiba, v. 10, n. 3, 551-590, set./dez. 2018 
especialmente para o anúncio profético da Palavra de Deus. Jesus é ungido pelo Espírito para o cumprimento de sua função messiânica. $\mathrm{O}$ autor dos Atos "historia a unção de Jesus com o Espírito na obra que ele inaugurou e na continuidade desta mesma obra, através dos homens e das mulheres chamados e enviados em missão" (BOFF, 1996, p. 29). É nessa perspectiva que Francisco concebe o Espírito da evangelização: força de Deus para a missão da Igreja. É fato que em vários números de sua Exortação salienta a vida no Espírito como elemento que antecede a evangelização na ordem da graça, mas seu destaque é certamente para o Espírito que faz a Igreja cumprir sua vocação radicada em sua própria natureza: a missão.

Se é verdade que o Espírito impele a Igreja para as mesmas coisas para as quais impele Jesus, então a Igreja deve repetir agora, na primeira pessoa, aquelas solenes palavras pronunciadas na sinagoga de Nazaré: O Espírito do Senhor está sobre mim...; ele me consagrou com a unção e me enviou para anunciar aos pobres uma alegre mensagem! (CANTALAMESSA, 2011, p. 38).

\section{O Espírito Santo e os evangelizadores}

A pessoa do evangelizador é um dos temas relativos à evangelização abordados por EG. Razão disso é o fato de que a missão eclesialé colocada em ato pelos batizados e batizadas que anunciam Jesus Cristo e seu Evangelho à humanidade. Em sua realidade mistérica, a Igreja é constituída como Povo de Deus, o que nos remete à participação efetiva de todos quantos são conscientes de sua pertença a este Povo na missão evangelizadora da Igreja. Desse modo, EG considera todos os batizados sujeitos ativos da evangelização, excluindo um possível reducionismo que considerasse apenas os ministros ordenados os únicos responsáveis e encarregados pelo anúncio do Evangelho. Feita essa consideração preliminar, dirigimos nosso olhar para a articulação teológica que Francisco realiza entre o Espírito da evangelização e os agentes da missão, que se apresenta como uma questão de natureza ântropo-pneumatológica.

EG aborda a pessoa do evangelizador a partir do que denomina “motivações para um renovado impulso missionário" (EG 262). O título do quinto capítulo de EG nos acena para essas motivações porque indica quais 
evangelizadores correspondem à nova etapa evangelizadora da Igreja: "evangelizadores com espírito" (EG 259). Em outras palavras, Francisco trata das motivações que o Espírito Santo suscita nos evangelizadores, sendo que tais motivações serão as referências para a leitura do texto de EG no que tange aos sujeitos eclesiais que atualizam a evangelização. Há muitas referências aos evangelizadores ao longo do texto de $\mathrm{EG}^{22}$, mas todas podem ser consideradas à luz das motivações mencionadas.

"Jesus quer evangelizadores que anunciem a Boa Nova não só com palavras mas sobretudo com uma vida transfigurada pela presença de Deus" (EG 259). A evangelização não é um momento específico da vida do evangelizador ou uma forma de discurso religioso eloquente e persuasivo. A evangelização é o testemunho vital de quem fez a experiência do amor de Deus manifestado em Cristo no Espírito Santo ${ }^{23}$. Daí o acento que Francisco confere às motivações da nova evangelização, pois do contrário bastariam os conhecimentos relativos às verdades da fé somados a boas técnicas de oratória.

A primeira motivação para evangelizar é o amor que recebemos de Jesus, aquela experiência de sermos salvos por Ele que nos impele a amá-Lo cada vez mais. Com efeito, um amor que não sentisse a necessidade de falar da pessoa amada, de a apresentar, de a tornar conhecida, que amor seria? Se não sentimos o desejo intenso de comunicar Jesus, precisamos de nos deter em oração para Lhe pedir que volte a cativar-nos (EG 264).

O evangelizador é aquele que renova continuamente sua experiência com o Deus Amor revelado em Jesus, aquele que alimenta cotidianamente seu encontro pessoal com Cristo por meio da oração e da contemplação. É no encontro com a Boa Nova do Pai, Jesus Cristo, que encontramos as respostas para nossas necessidades mais profundas e somos motivados pelo Espírito a comunicar o amor de Deus aos outros, amor que dá sentido à vida.

Para EG, este evangelizador é o discípulo missionário. "Em todos os batizados, desde o primeiro ao último, atua a força santificadora do

22 Cf. EG 10, 24, 78, 112, 121, 150, 151, 167, 259, 262, 268, 287.

23 Cf. EG 164. 
Espírito que impele a evangelizar" (EG 119). Pelo batismo recebido, cada membro do povo de Deus torna-se discípulo missionário. Todos os batizados, portanto, sendo discípulos missionários, são evangelizadores, sujeitos ativos da evangelização (EG 120). O discípulo missionário é o evangelizador da nova evangelização, o que implica que todos os batizados devem assumir seu protagonismo na ação evangelizadora.

Esta convicção transforma-se num apelo dirigido a cada cristão para que ninguém renuncie ao seu compromisso de evangelização, porque, se uma pessoa experimentou verdadeiramente o amor de Deus que o salva, não precisa de muito tempo de preparação para sair a anunciá-lo, não pode esperar que lhe deem muitas lições ou longas instruções. Cada cristão é missionário na medida em que se encontrou com o amor de Deus em Cristo Jesus; não digamos mais que somos 'discípulos' e 'missionários', mas sempre que somos 'discípulos missionários' (EG 120).

O encontro com Jesus, por conseguinte, é obra do Espírito Santo ${ }^{24}$. Pelo Espírito estabelecemos uma relação pessoal com o Senhor que nos ama. Ora, se esta é a fonte do protagonismo evangelizador dos batizados, temos que o discípulo missionário é plasmado pelo Espírito, pois o Deus que nos amou por primeiro ${ }^{25}$ nos convida a anunciar e testemunhar aos outros a maravilha de sentir-se amado com amor de Pai, no Filho, pelo Espírito. Assim, "é sempre importante saber que a primeira palavra, a iniciativa verdadeira, a atividade verdadeira vem de Deus e só inserindo-nos nesta iniciativa divina, só implorando esta iniciativa divina, nos podemos tornar também - com Ele e n'Ele — evangelizadores" (EG 112). O próprio Deus é o protagonista da evangelização pela ação do Espírito Santo, pois a primazia da graça não é outra senão a primazia do Espírito. Dito de outro modo, o discípulo missionário é todo batizado que realiza seu encontro pessoal com Cristo por obra do Espírito Santo e desde aí se sente impelido a evangelizar. Não se trata meramente de uma decisão pessoal, mas da ação do Espírito que nos faz participantes da missão de Jesus.

24 Cf. XIII ASSEMBLEIA GERAL DO SÍNODO DOS BISPOS. Proposta 36; DAp 240-242.

25 Cf. 1Jo 4,19. 
Esta realidade se faz presente em nossa vida por obra do Espírito Santo que também, através dos sacramentos, nos ilumina e vivifica. Em virtude do Batismo e da Confirmação somos chamados a ser discípulos missionários de Jesus Cristo e entramos na comunhão trinitária na Igreja ${ }^{26}$ (DAp 153).

Ao paradigma da Igreja em saída refere-se a ação evangelizadora dos discípulos missionários, porque a Igreja em saída é a comunidade dos discípulos missionários que "primeireiam", envolvem-se, acompanham, frutificam e celebram (EG 24). A saída missionária da Igreja, marcada por tais atitudes fundamentais, é o impulso do Espírito para a missão. Ademais, o discípulo missionário reconhece os contextos da evangelização, não por "um olhar puramente sociológico", mas com "o olhar do discípulo missionário que 'se nutre da luz e da força do Espírito Santo"' (EG 50). Ser discípulo missionário, portanto, "significa ter a disposição permanente de levar aos outros o amor de Jesus; e isto sucede espontaneamente em qualquer lugar: na rua, na praça, no trabalho, num caminho" (EG 127).

$\mathrm{Na}$ perspectiva de EG, a relação entre o Espírito Santo e os evangelizadores adquire seu sentido fundamental no âmbito das motivações do impulso missionário a que aludimos no início da presente sessão. Elas não apenas recapitulam o que o texto da Exortação indica como as marcas características do discípulo missionário sob a primazia da graça como também põem em destaque a ação do Espírito nos evangelizadores em prol da transformação missionária da Igreja. Os evangelizadores com espírito são os evangelizadores que se abrem sem medo à ação do Espírito Santo (EG 259). Abrir-se à ação do Espírito é sentir em si "o fogo do Espírito" (EG 261) que impele a evangelizar, o mesmo fogo que Francisco atribui ao querigma: "é o fogo do Espírito" (EG 164). Os evangelizadores, os discípulos missionários, "rezam e trabalham" (EG 262). Propostas parciais mutilam o Evangelho porque não transformam o coração do evangelizador. Tratam-se de falsas espiritualidades, porque rejeitam a ação do Espírito que "constrói a comunhão e a harmonia do povo de Deus" (EG 2117). O evangelizador experimenta "o encontro pessoal com o amor de Jesus que nos salva" (EG 64). O discípulo missionário é aquele

26 O capítulo V de EG nos recorda a espiritualidade que acompanha os discípulos missionários em Aparecida (FERNÁNDEZ, 2013, p. 128). 
que constantemente renova seu encontro pessoal com Cristo porque o ardor da evangelização está diretamente vinculado à experiência de ter conhecido Jesus e de tê-lo como amigo (EG 266). Tal experiência é igualmente eclesial na medida em que "o mistério da Igreja missionária está vinculado à relação existente entre o Espírito Santo e os batizados, como 'personalização' ou 'apropriação subjetiva' do mistério de Cristo" (AZCUY, 2014, p. 421).

O verdadeiro missionário, que não deixa jamais de ser discípulo, sabe que Jesus caminha com ele, fala com ele, respira com ele, trabalha com ele. Sente Jesus vivo com ele, no meio da tarefa missionária. Se uma pessoa não $\mathrm{O}$ descobre presente no coração mesmo da entrega missionária, depressa perde o entusiasmo e deixa de estar segura do que transmite, faltam-lhe força e paixão. E uma pessoa que não está convencida, entusiasmada, segura, enamorada, não convence ninguém (EG 266).

Outra motivação do evangelizador é o prazer espiritual de ser povo. Os discípulos missionários são povo de Deus. Sua pertença evangelizadora é a este povo, que é a Igreja. O mesmo Espírito que age por iniciativa de Deus em seu povo para constituir evangelizadores faz com que estes assumam sua missão no e como povo.

A missão no coração do povo não é uma parte da minha vida, ou um ornamento que posso pôr de lado; não é um apêndice ou um momento entre tantos outros da minha vida. É algo que não posso arrancar do meu ser, se não me quero destruir. Eu sou uma missão nesta terra, e para isso estou neste mundo. É preciso considerarmo-nos como que marcados a fogo por esta missão de iluminar, abençoar, vivificar, levantar, curar, libertar. Nisto uma pessoa se revela enfermeira no espírito, professor no espírito, político no espírito [...] (EG 273).

O individualismo, a crise de identidade e o declínio do fervor dos evangelizadores (EG 78) são males cujos antídotos são justamente as motivações que o Espírito suscita nos corações daqueles que se abrem à sua ação, que podem ser assim sintetizadas: aquele que se sente amado por Deus e que, por isso, é impelido pelo Espírito a anunciar e testemunhar 
aos outros esse amor. A marca do discípulo missionário, então, é a alegria, a alegria missionária (EG 21).

\section{Os carismas do Espírito para a missão}

O Concílio Vaticano II indicou a importância dos carismas como elementos decorrentes da natureza da Igreja e constituintes de sua missão. O Espírito, princípio da comunhão e da santidade da Igreja, "enriquece-a Ele e guia-a com diversos dons hierárquicos e carismáticos e adorna-a com seus frutos" (LG 4). O mesmo Espírito, “distribui também graças especiais entre os fiéis de todas as classes, as quais os tornam aptos e dispostos a tomar diversas obras e encargos, proveitosos para a renovação e cada vez mais ampla edificação da Igreja [...]” (LG 12). Com isso, o magistério conciliar reafirma, por um lado, o protagonismo de todo batizado no anúncio do Reino e da salvação - pois a iniciativa livre do Espírito concede a quem lhe aprouver dons carismáticos - e, por outro, a harmonia entre carismas e hierarquia com vistas à unidade, à renovação e à edificação da Igreja. Em ambos os casos, verifica-se a primazia do Espírito como dom e como princípio da comunhão e da santidade da Igreja. Em EG, Francisco dedica-se a uma breve análise da relação entre os carismas e a evangelização (EG 130-131), tendo como pressuposto o ensinamento conciliar em seu enfoque pneumatológico.

Para Francisco, os carismas não são um "patrimônio fechado, entregue a um grupo para que o guarde” (EG 130). O Espírito age como e quando quer ${ }^{27}$, de modo que os carismas que distribui aos cristãos não são propriedades, mas graças ordenadas ao bem comum. São também dinâmicos os carismas, à luz da dinamicidade do Espírito, que os dispõe conforme as necessidades da Igreja em cada época. Tanto ao magistério - a quem cabe julgar a autenticidade dos carismas - como aos demais cristãos impõem-se a atitude de não extinguir o Espírito ${ }^{28}$ mediante uma sincera abertura e fecunda docilidade à sua ação.

27 Cf. Jo 3,8.

28 Cf. 1 Tes 5,19 . 
Da definição negativa Francisco passa à definição positiva de carismas: "[...] são presentes do Espírito integrados no corpo eclesial, atraídos para o centro que é Cristo, de onde são canalizados num impulso evangelizador" (EG 130). A integração dos carismas na Igreja tem por razão primeira o próprio Espírito, que distribui tais dons para renovar e edificar a Igreja, conferindo-lhes unidade. $\mathrm{Na}$ esteira da doutrina conciliar, a eclesialidade de um carisma indica sua autenticidade, ou seja, é um carisma do Espírito aquele que está integrado harmoniosamente à vida do povo de Deus. Não é um carisma do Espírito aquele que se afirma a si mesmo em detrimento de outros carismas (EG 130), o que seria uma tentativa infundada de manipular ou mesmo absolutizar a ação do Espírito. Vale destacar o caráter gratuito dos carismas: são presentes, graças que o Espírito concede à Igreja com uma finalidade específica, que, vinculada ao critério da integração no corpo eclesial, salienta a natureza trinitária dos carismas: "Quanto mais um carisma dirigir o seu olhar para o coração do Evangelho, tanto mais eclesial será o seu exercício. É na comunhão, mesmo que seja fatigosa, que um carisma se revela autêntica e misteriosamente fecundo" (EG 130). À medida que um carisma, suscitado pelo Espírito, está orientado e orienta para Cristo, sempre mais a Igreja será testemunha da comunhão cuja fonte é a Trindade e a finalidade é a maior glória do Pai. A fecundidade de um carisma, segundo EG, não se refere à sua funcionalidade e eficiência para a vida da Igreja. Um carisma está ao serviço da "comunhão evangelizadora" (EG 130), comunhão dos carismas para o anúncio de Jesus Cristo: "E assim, mediante o Espírito Santo, que para utilidade comum reparte os carismas como quer, inspira no coração de cada um a vocação missionária" (AG 23). Francisco concebe a comunhão dos carismas como comunhão evangelizadora no Espírito.

As diferenças entre as pessoas e as comunidades por vezes são incômodas, mas o Espírito Santo, que suscita essa diversidade, de tudo pode tirar algo de bom e transformá-lo em dinamismo evangelizador que atua por atração. A diversidade deve ser sempre conciliada com a ajuda do Espírito Santo; só Ele pode suscitar a diversidade, a pluralidade, a multiplicidade e, ao mesmo tempo, realizar a unidade (EG 131). 
Com a consciência de que os carismas são dons do Espírito à Igreja, Francisco evidencia a necessidade de uma sincera abertura e de uma dócil confiança à ação do Espírito por parte dos sujeitos eclesiais. Não faria sentido que o Espírito dispensasse dons carismáticos diversos para a divisão da Igreja. Em EG, a divisão é resultado de particularismos e exclusivismos com pretensão de diversidade; e a uniformidade é resultado de generalizações e atitudes homogeneizantes com pretensão de unidade. "Isso não ajuda a missão da Igreja" (EG 131).

O Espírito Santo [...] concede também aos fiéis [...] dons particulares (cfr. 1Cor 12,7), 'distribuindo-os por cada um conforme lhe apraz' (1Cor 12,11 ), a fim de que 'cada um ponha ao serviço dos outros a graça que recebeu' e todos atuem, 'como bons administradores da multiforme graça de Deus' (1Ped 4,10), para a edificação, no amor, do corpo todo (cfr. Ef 4,1). A recepção destes carismas, mesmo dos mais simples, confere a cada um dos fiéis o direito e o dever de os atuar na Igreja e no mundo, para bem dos homens e edificação da Igreja, na liberdade do Espírito Santo, que 'sopra onde quer' (Jo 3,8) e, simultaneamente, em comunhão com os outros irmãos em Cristo [...] (AA 3).

De acordo com Boas (2015, p. 80), a concepção de carisma no Concílio Vaticano II foi ampliada a partir da pneumatologia paulina com vistas à sua inserção na eclesiologia conciliar de comunhão, que em EG assume contornos de "comunhão evangelizadora" (EG 130). Também o DAp explicita a realidade dos carismas como dons do Espírito na perspectiva da missionariedade da Igreja, sem a qual, igualmente para o Vaticano II e para Francisco, não é possível uma adequada abordagem teológica e pastoral dos carismas:

a partir de Pentecostes, a Igreja experimenta de imediato fecundas irrupções do Espírito, vitalidade divina que se expressa em diversos dons e carismas (cf. 1Cor 12,1-11) e variados ofícios que edificam a Igreja e servem à evangelização (cf. 1Cor 12,28-29). Através destes dons, a Igreja propaga o ministério salvífico do Senhor até que Ele de novo se manifeste no final dos tempos (cf. 1Cor 1,6-7) (DAp 150). 
Em EG, portanto, os carismas são concebidos não como elementos identitários de determinados grupos eclesiais. Os carismas são dons do Espírito para a comunhão evangelizadora da Igreja, pois, ao distribuir tais dons, o Espírito o faz com vistas à unidade da missão. Segundo Congar (2010, p. 25), a aceitação de uma possível oposição entre os carismas e as realidades institucionais seria uma forma de romper com a unidade da Igreja, pois "alguns pretenderiam manipular e ditar regras a tudo unicamente em nome do poder, sem espiritualidade; outros, anarquicamente, em nome do Espírito". Nesse caso, "faltaria a necessária dimensão pneumatológica da eclesiologia" (CONGAR, 2010, p. 25), que concebe os carismas e a instituição como realidades ordenadas à mesma finalidade: a construção da obra de Cristo. O Espírito Santo distribui os carismas como instrumentos para a evangelização e, por conseguinte, como sinais da unidade da Igreja, pois "é preciso reconhecer para cada tipo de dom e de operação seu lugar na edificação da Igreja” (CONGAR, 2010, p. 25).

\section{Espírito Santo, princípio da renovação eclesial ${ }^{29}$}

EG, na qualidade de Exortação Apostólica, propõe caminhos para a renovação da Igreja, caminhos que seguem o expediente do Concílio enquanto volta às fontes bíblicas e patrísticas para que, à sua luz, a Igreja explicite a novidade e o frescor do Evangelho na contemporaneidade. Nesse sentido, a evangelização é o caminho por excelência para a renovação da Igreja, pois a mesma Igreja "existe para evangelizar"30. O contínuo retorno à sua identidade e vocação mais profundas é o que dá à Igreja a possibilidade de renovar-se sem ceder à tentação de uma estagnação ou paralisia, pois sendo o Evangelho destinado a todos os homens e mulheres de todos os tempos, a Igreja, por mandato de Cristo, deve se encontrar sempre mais em condições de anunciar e testemunhar a Boa Nova em todo tempo e lugar. Considerando que o Espírito Santo é o

29 "Pela força do Evangelho [0 Espírito Santo] rejuvenesce a Igreja e renova-a continuamente e leva-a à união perfeita com o seu Esposo" (LG 4).

30 EN 14. 
princípio e o protagonista da ação evangelizadora, encontramos no texto de EG diversos elementos que nos indicam ser o Espírito igualmente o princípio da renovação da Igreja na medida em que a santifica e a impele para a missão. Por isso, ponderamos a seguir sobre a relação entre a evangelização, o Espírito Santo e a renovação da Igreja em EG.

No primeiro número de EG, Francisco acena para o primordial propósito de sua Exortação: "Quero, com esta Exortação, dirigir-me aos fiéis cristãos a fim de os convidar para uma nova etapa evangelizadora marcada por esta alegria e indicar caminhos para o percurso da Igreja nos próximos anos (EG 1)". A nova etapa evangelizadora a que Francisco faz referência é não só a principal motivação como é também, e prioritariamente, a primeira e mais urgente necessidade da Igreja contemporânea. Tal necessidade, para o Pontífice, possui um "significado programático" e "consequências importantes" (EG 25). Todos os temas, dimensões e elementos pertinentes à evangelização em EG constituem "um preciso estilo evangelizador" (EG 18), consecução da nova etapa evangelizadora da Igreja e princípio norteador de toda atividade eclesial. Com essa expressão, e suas consequências práticas, Francisco procura oferecer uma resposta ao anseio de renovação da Igreja proposto pelo Vaticano II. Para o Papa Bergoglio, o Vaticano II compreende a renovação da Igreja como um processo permanente de conversão eclesial por fidelidade a Jesus Cristo (EG 25). Citando Unitatis Redintegratio ${ }^{31}$, Francisco afirma: “Toda a renovação da Igreja consiste essencialmente numa maior fidelidade à própria vocação [...] A Igreja peregrina é chamada por Cristo a esta reforma perene. Como instituição humana e terrena, a Igreja necessita perpetuamente desta reforma" (EG 26). Dado que a vocação da Igreja é eminentemente missionária, Francisco admite (EG 27), seguindo as palavras de João Paulo II, que "toda a renovação na Igreja há de ter como alvo a missão, para não cair vítima duma espécie de introversão eclesial"32. Assim, EG concentra-se no processo de renovação eclesial a partir da "transformação missionária da Igreja" (EG 19), ou seja, da fidelidade à sua vocação fundamental, que exige uma contínua conversão e uma contínua

31 Cf. Unitatis Redintegratio 6.

32 JOÃO PAULO II. Exortação Apostólica Ecclesia in Oceania 19. 
reforma, cujos efeitos se dão na própria atividade evangelizadora da Igreja. Sendo o Espírito Santo o protagonista da evangelização, o "preciso estilo evangelizador" (EG 18) delineado por EG tem por protagonista o mesmo Espírito. No âmbito da renovação eclesial, não há fidelidade da Igreja à sua vocação e não há conversão missionária se se prescinde da ação do Espírito Santo. Para EG é evidente que a renovação da Igreja é obra do Espírito Santo, do Espírito da missão. Eis alguns aspectos concernentes à renovação da Igreja operada pelo Espírito Santo segundo EG.

O primeiro, e certamente o mais importante, é o querigma, "que deve ocupar o centro da atividade evangelizadora e de toda a tentativa de renovação eclesial" (EG 164). O querigma é o fundamento do "preciso estilo evangelizador" proposto por EG e o princípio de toda a renovação eclesial, não apenas cronológico, mas fundamentalmente teológico.

Ao designar-se como 'primeiro' este anúncio não significa que o mesmo se situa no início e que, em seguida, se esquece ou substitui por outros conteúdos que o superam; é o primeiro em sentido qualitativo, porque é o anúncio principal, aquele que sempre se tem de voltar a ouvir de diferentes maneiras e aquele que sempre se tem de voltar a anunciar, duma forma ou doutra (EG 164).

O querigma "é o fogo do Espírito que se dá sob a forma de línguas e nos faz crer em Jesus Cristo, que, com a sua morte e ressurreição, nos revela e comunica a misericórdia infinita do Pai” (EG 164). Do querigma derivam todos os demais aspectos propostos por Francisco para a renovação da Igreja. Destes, aspecto importante é o do anúncio renovado (EG 11), que, fundado no querigma, tem por consequência uma fecundidade evangelizadora que torna os fiéis sempre novos (EG 11). Trata-se da verdade de sempre - o Deus que nos amou infinita e incondicionalmente em Cristo - em sua relação com o hoje da Igreja. Quando a Igreja tem deslocado este referencial, passa a anunciar uma mensagem condicionada a um tempo e a um espaço, que pode responder a determinados contextos históricos, culturais e eclesiais e a outros não. A força renovadora do querigma reside no fato de que não é uma mensagem de ontem, mas realidade que se atualiza hoje: hoje Deus nos ama em Cristo, hoje comunica-nos a sua misericórdia. E não há como compreender 
a experiência do querigma à parte da ação do Espírito, pois é Ele que nos faz crer no Cristo que revela o amor do Pai. A perenidade do querigma tem sua razão de ser na ação do Espírito que transcende a temporalidade para nos comunicar a mesma graça que os apóstolos receberam no Pentecostes, graça que os conduziu imediatamente à missão. O querigma, portanto, renova a Igreja fazendo-a experimentar sempre de novo a realidade da Igreja nascente em Pentecostes, ou seja, a faz fiel à sua própria vocação.

O segundo aspecto, não menos importante, é o encontro pessoal com Jesus Cristo, que é o principal efeito do querigma. Diz Francisco: "Convido todo o cristão, em qualquer lugar e situação que se encontre, a renovar hoje mesmo o seu encontro pessoal com Jesus Cristo ou, pelo menos, a tomar a decisão de se deixar encontrar por Ele, de O procurar dia a dia sem cessar" (EG 3) ${ }^{33}$. Nossa relação com Cristo é pessoal, experiencial, existencial. $\mathrm{O}$ encontro com Cristo se dá quando descobrimos que somos amados com o amor do Pai revelado em Jesus. Este amor, então, confere um novo sentido à vida e redimensiona nossa relação com Deus.

Somente graças a este encontro - ou reencontro - com o amor de Deus, que se converte em amizade feliz, é que somos resgatados da nossa consciência isolada e da autorreferencialidade. Chegamos a ser plenamente humanos, quando somos mais do que humanos, quando permitimos a Deus que nos conduza para além de nós mesmos a fim de alcançarmos o nosso ser mais verdadeiro. Aqui está a fonte da ação evangelizadora. Porque, se alguém acolheu este amor que lhe devolve o sentido da vida, como é que pode conter o desejo de o comunicar aos outros? (EG 8)

No Pentecostes, os apóstolos vivenciaram a experiência do encontro pessoal com Cristo e, logo em seguida, saíram para anunciá-lo. O Cristo que haviam conhecido e com quem haviam caminhado, foi-lhes revelado de um modo novo, como manifestação plena do amor de Deus. Ora, foi o Espírito que os fez experimentar o amor do qual eram destinatários mas que ainda não haviam reconhecido como o sentido fundamental de suas

33 "Ao início do ser cristão, não há uma decisão ética ou uma grande ideia, mas o encontro com um acontecimento, com uma Pessoa que dá à vida um novo horizonte e, desta forma, o rumo decisivo" (Deus Caritas Est 1).

Rev. Pistis Prax., Teol. Pastor., Curitiba, v. 10, n. 3, 551-590, set./dez. 2018 
vidas. Se o encontro pessoal com Cristo é a fonte da ação evangelizadora da Igreja, que é missionária por natureza, a renovação eclesial proposta por EG não pode ser compreendida se a experiência do encontro com Cristo não levar a Igreja e os cristãos à saída missionária. "Um novo Pentecostes é uma fecunda irrupção do Espírito que suscita uma nova vitalidade missionária para compartilhar o dom do encontro com Cristo. O Espírito Santo é a força interior que encoraja a dimensão missionária da vida cristã para irradiar a vida em Jesus Cristo" (GALLI, 2014, p. 33, trad. nossa) ${ }^{34}$.

A primeira motivação para evangelizar é o amor que recebemos de Jesus, aquela experiência de sermos salvos por Ele que nos impele a amá-Lo cada vez mais. Com efeito, um amor que não sentisse a necessidade de falar da pessoa amada, de apresenta-la, de torná-la conhecida, que amor seria? (EG 264)

Não é por acaso que Francisco inscreve "o encontro pessoal com o amor de Jesus que nos salva” (EG 264) no rol das motivações que orientam o renovado impulso missionário, motivações estas que exprimem o espírito da evangelização, o Espírito Santo. Em outras palavras, é o Espírito Santo que nos faz encontrar o Senhor.

Esta convicção, porém, é sustentada com a experiência pessoal, constantemente renovada, de saborear a sua amizade e a sua mensagem. Não se pode perseverar numa evangelização cheia de ardor, se não se está convencido, por experiência própria, que não é a mesma coisa ter conhecido Jesus ou não $\mathrm{O}$ conhecer, não é a mesma caminhar com Ele ou caminhar tateando, não é a mesma poder escutá-Lo ou ignorar a sua Palavra, não é mesma coisa poder contemplá-Lo, adorá-Lo descansar n'Ele ou não o poder fazer. Não é a mesma coisa procurar construir o mundo com o seu Evangelho em vez de fazê-lo unicamente com a própria razão (EG 266).

O querigma como núcleo do processo de renovação eclesial vinculado à experiência do encontro pessoal com Cristo engendra uma

34 "O projeto de Francisco se pode resumir assim: a Igreja se reforma pela conversão missionária; a conversão e a missão renovam a Igreja. A Ecclesia semper reformanda é uma Ecclesia in statu conversionis e uma Ecclesia in statu missionis (GALLI, 2014, p. 39, trad. nossa). 
pastoral que se alimenta do "frescor original do Evangelho" (EG 11), que aponta sempre novos caminhos, novos métodos, novas formas de expressão e novas palavras que se traduzem em sinais para a renovação do mundo e não só da Igreja. Sendo assim, "toda a ação evangelizadora autêntica é sempre "nova" (EG 11), pois o Evangelho é sempre novo ${ }^{35}$.

Toda renovação eclesial implica um retorno ao mais nuclear da fé cristã, à vivência cristã das primeiras comunidades, talvez encobertas pelas doutrinas, normas, regulamentações, tradições que se lhes agregaram ao longo da história, certamente para explicitar e salvaguardar este núcleo evangélico, mas que não deixaram de obscurecê-lo por ocuparem um lugar central que não é o seu (MIRANDA, 2014, p. 412).

Desse modo, se é pelo Espírito que experimentamos o amor de Deus e se toda a evangelização é, por isso, sempre nova, é o Espírito que renova a ação pastoral da Igreja, é Ele o fundamento da conversão pastoral e missionária (EG 25), que transforma tudo (EG 27), na contramão da autorreferencialidade (EG 27). O "fez-se sempre assim" (EG 33) está vinculado às concepções parciais e aos condicionamentos histórico-pastorais da Igreja, ao passo que a experiência do querigma e do encontro pessoal com Cristo é a de "se deixar conduzir pelo Espírito, renunciando a calcular e controlar tudo e permitindo que Ele nos ilumine, guie, dirija e impulsione para onde Ele quiser. O Espírito Santo bem sabe o que faz falta em cada época e em cada momento" (EG 280).

Sob o prisma da evangelização, todos os recursos humanos e técnicos devem estar subordinados à ação do Espírito. A proposta renovadora de EG compreende-se em grande parte a partir desse ponto. De acordo com Fernández (2016, p. 584), a abertura à ação do Espírito faz retornar à objetividade do Evangelho, orienta ao essencial e reforma as estruturas obsoletas, purificando-as. "O Espírito Santo não é um Espírito de inovação, mas de incessante renovação da força de origem, isto é, do Evangelho

35 "0 objetivo desta reflexão é fazer emergir a intenção de fundo que move e justifica os pronunciamentos e as decisões deste papa. Porque não se trata somente de reformar a Cúria romana, de solucionar a questão dos recasados e dos homossexuais na Igreja, de incutir certa sobriedade e maior espírito de serviço no clero e mesmo na instituição eclesial. Julgamos que a força motriz de Francisco esteja num nível mais profundo, mais espiritual e, simplemente, mais evangélico" (MIRANDA, 2015, p. 89). 
de Jesus Cristo, [porque] a tarefa do Espírito Santo é continuar a tornar presente Jesus Cristo na sua novidade" (KASPER, 1989, p. 30, trad. nossa).

A vida nova, a reforma permanente da Igreja, sua transformação e saída missionárias são a vida no Espírito, autêntica vida evangélica, constituída como graça mas também mediante o esforço de conversão. No Mistério da Igreja, o Espírito a santifica e vivifica, e todos os fiéis tem acesso ao Pai, por Cristo, no Espírito (LG 4). Logo, é o Espírito que "pela força do Evangelho rejuvenesce a Igreja e renova-a continuamente" (LG 4). Nesse sentido, o ensinamento conciliar torna evidente que o primeiro e o último critério da vitalidade da Igreja é Jesus Cristo, cuja vida toma forma na Igreja e nos cristãos pela ação do Espírito Santo.

Dito de outra maneira, a missão é a vida da Igreja sob o dinamismo evangelizador do Espírito e não uma tarefa sujeita aos critérios mundanos. Quando isso ocorre, há o que Francisco chama de "mundanismo espiritual" (EG 93). Uma fé subjetivista, na qual "a pessoa fica enclausurada na imanência da sua própria razão ou dos seus sentimentos" (EG 94), e a atitude de confiança absoluta nas próprias forças alimentam esse mundanismo. Trata-se de um "imanentismo antropocêntrico" (EG 94). "Este mundanismo asfixiante cura-se saboreando o ar puro do Espírito Santo, que nos liberta de estarmos centrados em nós mesmos [...]" (EG 97).

A saída missionária da Igreja pressupõe a conversão do coração, a santidade, que "incessantemente se manifesta, e deve manifestar-se, nos frutos da graça que o Espírito Santo produz nos fieis" (LG 39). Para Francisco, a santidade da Igreja evangelizadora frutifica na alegria do Evangelho, que é renovada na missão. Pastoralmente, a conversão do coração se materializa na conversão das estruturas, fazendo com que "todas elas se tornem mais missionárias” (EG 27). Para Congar (2010, p. 85), é o Espírito que "impulsiona para frente a causa do Evangelho", suscitando iniciativas, missões, obras,... "Ele inspira as reformas necessárias e sabe preservá-las das meras manipulações externas para fazer prevalecer uma reconformidade com o espírito de Jesus".

Em EG, portanto, a renovação eclesial pode ser concebida como conversão pastoral e missionária, pois o querigma e o encontro pessoal com Cristo são os modos pelos quais o Espírito impele, motiva e projeta a Igreja em sua saída missionária, grande paradigma da Igreja nascente 
em Pentecostes. A renovação eclesial é a renovação na missão a partir do encontro pessoal com Cristo no Espírito Santo.

\section{Conclusão}

Ao concluirmos o presente trabalho, acenamos para o fato de que o itinerário argumentativo apresentado nos possibilita a elaboração de uma síntese a partir da pneumatologia de EG. Trata-se de uma síntese que se configura como uma pneumatologia missionária: um conjunto de elementos pneumatológicos que se articulam organicamente com vistas à compreensão da relação entre Espírito e missão no período pós-conciliar.

Perguntamo-nos por que Francisco dedica o último capítulo de sua Exortação à Pessoa do Espírito Santo em sua relação com a evangelização? Porque o Espírito Santo é o ator principal da evangelização e tudo o que é dito em EG não adquire seu sentido fundamental se a ação evangelizadora despreza a ação do Espírito. Dado esse pressuposto, poderíamos questionar por que Francisco não iniciou sua Exortação com o referido tema, uma vez que é o critério teológico-formal para a interpretação de seu texto. Ao que nos parece, assim o fez por duas razões: a primeira, para que a leitura do texto exortativo fosse concluída recordando o fundamento da evangelização; a segunda, para que o leitor se sentisse motivado a retornar ao texto para uma releitura a partir do Espírito da evangelização. Foi isso que fizemos, e nesse processo de releitura em perspectiva pneumatológica pudemos observar os diversos elementos que constituem a pneumatologia missionária em EG.

Esta pneumatologia missionária articula elementos numa totalidade que caracteriza a relação entre Espírito, Igreja e Missão, tornando-se um significativo resgate da Pessoa do Espírito Santo e sua ação na Igreja. Assim, a pneumatologia missionária em EG reflete duas das mais importantes temáticas teológicas do pós-Concílio, que impactam decisivamente a ação evangelizadora da Igreja e os evangelizadores.

A pneumatologia missionária em EG, em linhas gerais, apresenta:

Em termos de uma teologia trinitária, uma consideração da Pessoa do Espírito Santo como amor do Pai e do Filho, fonte da ação evangelizadora. 
Em termos de uma eclesiologia pneumatológica, o Espírito como protagonista da missão, à luz do Pentecostes, pois é o Espírito que impulsiona a Igreja e os cristãos a evangelizar, evangeliza a mesma Igreja e os evangelizadores e já está presente no mundo antes mesmo da evangelização da Igreja. Em termos de uma antropologia pneumática, o fato de que os evangelizadores assim se constituem na dinâmica do Espírito: testemunhas que exprimem a unidade entre discipulado e missão na pessoa do discípulo missionário. Em termos eclesiológicos, é o Espírito que renova a Igreja, fazendo-a retornar a Cristo. Com isso, o Espírito da evangelização é prioritariamente o Espírito da reforma missionária da Igreja. Ou seja, o Espírito renova a Igreja na missão.

Enfim, a pneumatologia missionária em EG pode ser concebida como unidade teológica a partir de seus termos e das relações essenciais que estabelecem entre si, não sendo possível considerá-los de outra forma: a missão é com Espírito e o Espírito não faz outra coisa senão impulsionar para a missão. Tal articulação teológica e pastoral se dá na Igreja, que é, ao mesmo tempo, meio pelo qual o Espírito age em prol da missão e o sujeito prioritário da missão.

\section{Siglas}
AA Decreto Apostolicam Actuositatem
AG Decreto Ad Gentes
DAp Documento de Aparecida
$\mathrm{DeV} \quad$ Carta Encíclica Dominum et Vivificantem
EG Exortação Apostólica Evangelii Gaudium
EN Exortação Apostólica Evangelii Nuntiandi
LG Constituição Dogmática Lumen Gentium 


\section{Referências}

AZCUY, V. R. La "trama interna” de Evangelii Gaudium. Ensayo sobre la fuerza de la espiritualidad evangelizadora. Perspectiva Teológica, Belo Horizonte, v. 46, n. 130, p. 407-432, set./dez. 2014.

BENTO XVI. Carta Encíclica Deus Caritas Est sobre o amor cristão. 3. ed. São Paulo: Paulinas, 2006.

BOAS, A. V. Carisma. In: PASSOS, J. D.; SANCHEZ, W. L. (Coord.). Dicionário do Concílio Vaticano II. São Paulo: Paulus, 2015. p. 78-80.

BOFF, C. M. Espiritualidade e Pastoral. Sugestões para a pastoral da educação. Revista Eclesiástica Brasileira, Petrópolis, v. 75, n. 298, p. 369-389, abr./jun. 2015.

BOFF, L. Espírito e Missão na obra de Lucas-Atos: para uma teologia do Espírito. São Paulo: Paulinas, 1996.

CANTALAMESSA, R. O Espírito Santo na vida de Jesus. Trad. Luiz João Gaio. São Paulo: Loyola, 2011.

CANTALAMESSA, R. Vem, Espírito Criador: Meditações sobre o Veni creator. São Paulo: Canção Nova, 2014.

CATÃO, F. A Teologia do Espírito Santo: novas perspectivas. Revista de Cultura Teológica, São Paulo, v. 17, n. 66, p. 93-112, jan./mar. 2009.

CONCÍLIO VATICANO II. Constituição Dogmática Lumen Gentium. In: CONCÍLIO VATICANO II. Vaticano II: mensagens, discursos e documentos. 2. ed. Trad. Francisco Catão. São Paulo: Paulinas, 2007. p. 185-247.

CONCÍlIO VATICANO II. Decreto Ad Gentes. In: CONCÍLIO VATICANO II. Vaticano II: mensagens, discursos e documentos. 2. ed. Trad. Francisco Catão. São Paulo: Paulinas, 2007. p. 400-439.

CONFERÊNCIA EPISCOPAL LATINO-AMERICANA. Documento de Aparecida: texto conclusivo da V Conferência Geral do Episcopado Latino-Americano e do Caribe. 7. ed. São Paulo: Paulinas; Paulus; Brasília: CNBB, 2008. 
CONGAR, Y. "Ele é o Senhor e dá a vida”. 2. ed. Trad. Euclides Martins Balancin. São Paulo: Paulinas, 2010.

FERNÁNDES, V. M. La espiritualidad integradora que propone Aparecida. In: GALLI, C. et al. De la Misión Continental a la Misión Universal. Buenos Aires: Docencia, 2013. p. 121-136.

FERNÁNDES, V. M. Il Vangelo, lo Spirito e la riforma ecclesiale alla luce del pensiero di Francesco. In: GALLI, C. M.; SPADARO, A. (orgs.). La riforma e le riforme nella Chiesa. Brescia: Queriniana, 2016. p. 582-589.

FRANCISCO. Exortação Apostólica Evangelii Gaudium sobre o anúncio do Evangelho no mundo atual. São Paulo: Paulinas, 2013.

FRANCISCO. Homilia na Quinta-feira da 3a Semana da Páscoa. Disponível em: <http:// br.radiovaticana.va/news/2016/04/14/papa_a_docilidade_ao_esp\%C3\%ADrito_ leva_avante_a_igreja/1222655>. Acesso em: 10 out. 2016.

GALLI, Carlos María. Dio vive in città. Verso una nuova pastorale urbana. Roma: Libreria Editrice Vaticana, 2014.

GALLI, C. M. La teología pastoral de Evangelii Gaudium en el proyecto misionero de Francisco. Teología, Buenos Aires, n. 114, p. 23-59, ago. 2014.

HACKMANN, G. L. B. A Amada Igreja de Jesus Cristo: Manual de Eclesiologia como Comunhão Orgânica. 2. ed. Porto Alegre: EDIPUCRS, 2013.

JOÃO PAULO II. Carta Encíclica Dominum et Vivificantem sobre o Espírito Santo na vida da Igreja e do mundo. Disponível em: <http://w2.vatican.va/content/john-paul-ii/pt/encyclicals/documents/hf_jp-ii_enc_18051986_dominum-et-vivificantem.html>.

JOÃO PAULO II. Exortação Apostólica Ecclesia in Oceania. Disponível em: <http:// w2.vatican.va/content/john-paul-ii/pt/apost_exhortations/documents/hf_jp-ii_exh_20011122_ecclesia-in-oceania.html>. Acesso: 18 out. 2016.

JUNCOS, D.; LIBERTI, L. O. Evangelii nuntiandi y Evangelii gaudium: ¿El mismo paradigma missioneiro? Continuidades, novedades y desafios. Teología, Buenos Aires, n. 116, p. 49-71, abr. 2015. 
KASPER, W. Lo Spirito Santo dà la vita: Meditazione teológica sullo Spirito Santo. Casale Monferrato: Piemme, 1989.

MAÇANEIRO, M. Paternidade de Deus e mistério trinitário no ensino de Paulo VI e João Paulo II. Atualidade Teológica, Rio de Janeiro, v. 20, n. 54, p. 644-663, set./dez. 2016.

MIRANDA, M. F. A experiência do Espírito Santo. Abordagem teológica. Perspectiva Teológica, Belo Horizonte, v. 30. n. 81, p. 161-181, maio/ago. 1998.

MIRANDA, M. F. Uma renovação eclesial que brota do Espírito Santo. Revista Eclesiástica Brasileira, Petrópolis, v. 75, n. 297, p. 88-104, jan./mar. 2015.

PAULO VI. Exortação Apostólica Evangelii Nuntiandi sobre a evangelização no mundo contemporâneo. 22. ed. São Paulo: Paulinas, 2011.

PÉREZ, A. C. La alegría del Evangelio y la reforma de la Iglesia. Líneas fundamentales de la Exhortación apostólica "Evangelii Gaudium". Misiones Extranjeras, Madrid, n. 260-261, p. 318-332, maio/ago. 2014.

SPADARO, A. Radici, struttura e significato della prima Esortazione Apostolica di Papa Francesco. In: FRANCESCO. Evangelii Gaudium: Testo integrale e comento de "La Civiltà Cattolica”. Roma: Ancora, 2014. p. 151-169.

XIII ASSEMBLEIA GERAL DO SÍNODO DOS BISPOS. Lista Final de Propostas. Synodus Episcoporum Bollettino, 2012. Disponível em: <http://www.vatican.va/ news_services/press/sinodo/documents/bollettino_25_xiii-ordinaria-2012/ xx_plurilingue/b33_xx.html>. Acesso em: 2 maio 2017.

Recebido: 30/08/2018

Received: 08/30/2018

Aprovado: 25/10/2018

Approved: 10/25/2018 